\title{
SPECIFIC ASPECTS OF PROFESSIONAL THINKING OF MUSICIAN-PERFORMERS
}

\section{Zaets V. M.}

\section{INTRODUCTION}

The relevance of this topic is based on the need to summarize scientific achievements, methodological, practical and performing experience in musical and performing practice, which concentrates and generates further development of this type of art. The previous achievements of musical and performing arts lead to the search for a perspective orientation of the artist to reveal new possibilities of influence not only on a concrete person, but also on social and interpersonal relationships.

The essence of this work is to realize the perfection of the professional and creative directions of the musician-performer in the musical performing arts. These impulses are made and realized on the experience of learning, practical work and scientific searches in accordance with the traditions of performing arts and the theoretical thought of domestic and foreign specialists.

The task of the artist is to seek and obtain certain intentions through methods, techniques and means by which he - when realizing them reflects his personality and music worldview and passes it to specific listeners. That is why the problem of human thinking in general is always active, meaning, it is in the procedural state, since as an individual, its natural environment assimilates and generates new feelings, and, therefore, directly influences the course of mental (intellectual-sensual) processes.

The processality of this two-way dynamic (in the broad sense) of the psychological modification is infinite, and therefore the analysis through synthesis, as well as synthesis through analysis in the disclosure of the laws here, also has time-procedural, continuously renewable nature. This is the main source of the essence of inter-assimilation ties in a specific musical-performing thinking, which determines the continuing relevance of their research. Consequently, the continuous evolution of human 
consciousness determines the direction of scientific searches in the disclosure of certain laws of its functioning, which reveals the professional (in this case - executive-musical) relevance of the study of this topic.

The conceptual approach chosen by us is probably promising to reveal the laws of the existence of musical and performing arts. In this direction, we investigate such aspects of the interpretive thinking of the performer, which have not yet been identified in previous scientific researches on this topic.

Each component of this multifaceted phenomenon-process has its own peculiarities of influence on the listener. Therefore, we consider this holistic process in its separate aspects as some relatively independent phenomena in order to realize the significance of each of them.

\section{Authenticity as the genesis of the mental thinking of the musician-performer}

Authenticity is seen, first of all, as a given historical experience, recorded in certain graphic records and in traditional verbal and song broadcasting. Our task is to substantiate the significance of the concept of authenticity in the context of the study of problems of performing thinking.

What is related to these concepts? If authenticity is the primary source, then the performance must implement it with its specificperforming means (the logic of intonation of sound combinations in conjunction with the metro-rhythmic organization and dynamics).

Primary source is a relative concept, literally, with respect to something else. If the primary source exists in relation to one's own awareness of the person, then it is exactly that. But for another person it can conditionally exist as such that the given person already generates a source of subsequent generations based on the given source. That is, authenticity is in the broad sense a procedural phenomenon; on the one hand, relative to previous achievements, on the other hand, as the primary source of prospects for the formation of consciousness and prediction of the character of the efficiency of descendants.

What can be understood under the term authentic? First of all, it corresponds to the original. The original can be found continuously, because continuity is not a temporary phenomenon. It is eternal. When we understand the complexity of this concept, we admit the following idea: 
authenticity is a concept that concentrates in itself universal concepts, but, in terms of concreteness it is dispersed. After all, if, for example, we take the most sacred in human life, its birth, then the mother's mother and father are the primary source for the child. And what would be the more primary source, the previous generations? Therefore, it is logical to answer this question more specifically: the definition - the primary source - means the creation of new achievements; that is, the previous one is the primary source of its consequences.

Hence the phenomenon that is historically fixed becomes the primary source.

Man is brought up by experience of previous generations (primary sources). To the existing one, it adds something new; because the human genotype is inexhaustible in the original originality. There is a paradoxical paradigm: a person is brought up on the primary sources, thus creating his own source for the future. What then is the essence of the concept of authenticity?

The awareness of the concept of authenticity in its various manifestations gives rise to the following thoughts: if it is conventionally considered to be an absolute source of natural origin, for example, a water source, then how in this case should one relate to the formula of water (H20), which consists of two genuinely older elements - oxygen and hydrogen. It is clear that the more authentic are the constituents, which, in combination, form a new quality - water. But, on the other hand, the source existed much earlier than the inventions of scientific searches of scientists, which determined the composition of water. There is a dilemma understanding the principle of primary and secondary origin of the concept. Similar considerations can be infinite. But, if we take as a basis the fact that a person needs, first of all, not a formula, namely a source (water), then, of course, the basis of the authentic in this case should be considered the water source.

Another understanding of authenticity lies in the fact that it is the present that is also the basis of something historical and authentic, and it is there for the future. Thus, it is a question of the historical-procedural understanding of the concept of authenticity, which, in turn, raises the problem of applying the analogy of comprehension of previous experience to contemporary musical and performing arts. One of the answers to this 
question is given by O. Sokol: "When choosing articulatory elements in general, one must be guided by the need to take into account the distribution and change of breath, as well as the presence of a caesura in the general intonational-artistic flow (direction). These components, while diluting the musical fabric, are at the moment necessary for the purity of perception and "understanding" their integrity. They are created based on unlikeliness of the motives, which turn the "musical" texture into a whole - in life as expressive speech. Otherwise, the time-consuming intonation stream often turns into a badly digested sound "porridge"", The above-mentioned motivates for further reflection. Namely: if we consider the ancient periods of human development, when its language and rhythmic movements were spontaneous, that is, unformed, unconscious (exclamations, unorganized gestures, etc.), then how do you relate to this period? Can it be considered authentic? On the one hand, yes, because the rhythmic-language intonations that were original were originated, that is, they were originally for their own time. On the other hand, considering the formation of human culture in general, outside a specific historical period, we cannot forget to recognize the primary processes of formation of human communication as the basis of authentication.

Primary source as authentic, is considered by us as a multi-spectral phenomenon and is relevant to all historical-active processes of human consciousness (physiological needs, spiritual motivations). As for the physiological needs of man, they can be considered as stable, because they are genetic. Spirituality of human needs has a mobile-procedural character as a result of modification of the consciousness of the human community, which creates traditions and novelty due to the "polarization of skills" in the process of development of a particular environment (family, family, nation, people ...). That is, if the interpretation of concepts is limited by the polarity of the comparisons, then they give rise to the opposition of thoughts about the possible coexistence of them (we mean the controversies of scientists about understanding the meaning of the concepts of authenticity, tradition, innovation), which is logical.

1 Сокол А. Исполнительские ремарки, образ и музыкальный стиль. Одесса: Моряк, 2007. 276 с. 
Consequently, we must consider the contradictions that arise in the realization of these concepts and to identify an objective possibility regarding their creative potential and artistic expediency in the musicalperforming process.

Authenticity is the basis in the understanding of the heritage, because the acquired must never be forgotten. Authentic takes on the importance of architectonics in subsequent searches. Therefore, the present is impossible without previous achievements in the material and spiritual spheres.

The ethics of the musician-performer, who seeks to provide a scientific interpretation of the historical, including authentic achievements, contributes to the understanding of what was created for him. We are referring to the opinion of Academician B. Asafiev: "The advanced audience accepted the music of Mussorgsky" without corrections", and "censorship of professionals", in relation to a peculiar and independent phenomenon of Russian musical culture, was very cruel. And what is the pseudo mask here is that all "corrections" are made to improve the volume! - Who is asking you about this? Then correct the language of L. Tolstoy and the paintings of I. Repin from the positions of the following "grammarians" and artists of the impressionistic world-colored-colored scale" . This statement by B. Asafiev testifies to the care of the relation to the already existing source - authentication. The author fixes everything that is consistent with the perception of the original, and refuses prematurely someone's vision of creative processes.

In what, at least, the criterion of understanding this concept in the situations described and how to determine it? And, in general, is it possible?

The constructive vision in the disclosure of this notion is found in the following: "It is impossible to feel the soul of the people, his dreams, hopes, experiences in different periods of history without studying the song ethnos in the entire completeness of its poetic content. It is necessary to accumulate knowledge of folklore by memorizing and executing as many folk songs as possible, dumas, necessarily with full poetic text, and in

\footnotetext{
${ }^{2}$ Асафьев Б. Избранные труды: в 5 т. М.: АН СССР, 1957. Т. 5.388 с.
} 
samples of instrumental folklore - techniques of improvisation, characteristic rhythmic-intonation turns, podcast polyphony, etc"3.

From the general musicology system of scientific concepts and terms concerning authentication, one must choose the most significant ones - to understand its function in musical performances.

Recall that authentic is true, which comes from the original source and corresponds to the original. But the original in translation from French to Latin means (“... [French original $\leq$ Latin originalis $\leq$ origo - origin”] ...) a similar content of authenticity ${ }^{4}$. Therefore, there is no need to repeat the word "corresponds to the original" in determining the concept of authenticity, namely: more concentrated - as a natural phenomenon, the primary source. So, in the future, in order to prevent semantic misunderstandings, we will be guided by this definition.

Is it possible to consider the phenomenon not as a component of twopronounced understanding of the concept of the phenomenon-the primary source, but as a phenomenon itself, which is a source? You can, if you consider it as something new (productive, that is, what creates) in relation to the already existing one. Otherwise, it is not able to be such because it has no purely reproductive content.

So, if we apply the notion of a dual name - the phenomenon-the primary source - to the musical-performing practice, then what does the figurative understanding of this "phenomenon-the primary source" mean?

There are many views and understandings of authenticity among composers, performers, musicologists. One of the points of view is the understanding of authenticity as the fixed connections of musical graphics of the most ancient formations (musical works, song arrays). This point of view is adhered by collectors of ancient folklore, other traditions are not recorded in the musical record, but still preserved in a living sound, transmitted from generation to generation. In this sense, non-civilized nations are characterized by unstable stability: tribes, peoples, such as Aborigines (African, Indian, Australian, etc.).

${ }^{3}$ Давидов М. Теоретичні основи формування виконавської майстерності баяніста. К.: Музична Україна, 1997. 240 с.

${ }^{4}$ Сучасний словник іншомовних слів [уклад. О. Скопненко, Т. Цимбалюк]. Київ: Довіра, 2006. 789 с. 
Let's take a look at some aspects of understanding authenticity: performance-authenticity-genre. Genre (French ... - genus, genre, genre, genre - genus, tribe ...) - historically formed type of literary work (novel, novel, narrative), synthesis of characteristic features of the content and form of a certain type of works ....".

The process of forming a particular genre in art is the primary source, along with the existing fixed samples, in a concretely formed form. For example, the processing of folk songs, where the melody is the primary source (authentication), and the methods of its processing - the essence of the genre. Or the transcription, in which the original work itself is the primary source, and transcription techniques reveal its genre features. Consequently, one of the principles of understanding authenticity as a problem is the principle of relativity, that is, the comparison of primary and secondary aspects.

Interpretation of a musical work, in the broad sense, is also not devoid of authenticity. It is expedient to consider it from the point of view of performance practice in the context of its methodological guidelines. Interpretation of a musical composition is quite possible to be considered as the primary source when creating a certain figurative and artistic paradigm. In relation to the sheet music, the source-interpretation turns out to be a "double dominant", that is, "the original source in the original". If the original source exists constantly at all times and can be viewed in comparison with other primary sources and, moreover, as a frozen modelmodel, then this is a different understanding of authenticity.

It is important to understand and to take into account also the concrete personality because what is understood by one person may not be acceptable to another if it does not give it a sense of informative and sensual novelty. When, for a particular subject, information is striking, it contributes to its perception of the previous one.

In the musical and performing arts, the primary sources of thought are embodied in various aspects of the vision of the generally accepted canons of perception of the surrounding reality.

${ }^{5}$ Сучасний словник іншомовних слів [уклад. О. Скопненко, Т. Цимбалюк]. Київ: Довіра, 2006. 789 с. 
Along with the concept of authentication there is the notion of folklore ("English ... folk-lore letters - folk wisdom) - oral folk art (fairy tales, proverbs, songs, etc." $)^{6}$.

It is obvious that the concept of authenticity, tradition, folklore undoubtedly have common essential roots. What among these roots is generally genetic (ontogeny) and what is their difference (phylogeny)? The notions of onto - and phylom are purposely isolated (philo-without ontimpossible) for the sake of the flexibility of the interpretation of this question.

Tradition ( $\leq 1$. Tradition - transfer: 1$)$ tastes, rules of conduct, ideas, norms, that were historically passed from generation to generation; custom, established in behavior, everyday life"7.

Tradition is a concept that points to phenomena that are historically formed. And if you consider a certain segment of history - this is one vision of the phenomenon. If you consider this phenomenon in historical conditions, naturally there are new aspects of its perception, and this novelty introduces certain adjustments in understanding the notion of tradition. Logically there is a reasonable question: how to determine the time period of becoming a tradition in order to become stable, meaningful and transmitted? After all, there are life traditions, and along with them there are those that arose in the recent past. How are these processes reflected in musical and performing arts?

As for authentication, these thoughts correspond to the very nature of this concept, which is not subject to lifelong stabilization because it exists in a procedural comparison with other phenomena of social being and consciousness. If we consider these interrelations, we define the following: "A folk song is the primary source of the spirituality of musical art because it provides additional information for the in-depth definition of life, everyday life, important historical events, cultural heritage, full of humanistic ideas, history of struggle of the people for the better of the

${ }^{6}$ Сучасний словник іншомовних слів [уклад. О. Скопненко, Т. Цимбалюк]. Київ: Довіра, 2006. 789 с.

${ }_{7}$ Сучасний словник іншомовних слів [уклад. О. Скопненко, Т. Цимбалюк]. Київ: Довіра, 2006. 789 с. 
future. It uses the true culture of human feelings, in particular, the musician",

To the above, add the following: there are immutable primary sources that remain authentic forever for this nation, people in the form of cultural achievements (fairy tales, proverbs, songs, etc.).

Consequently, the following comparison leads to the following conclusions:

- the study of this problem requires a professional methodology for its disclosure;

- a specific methodology is based on knowledge of the specifics of this type of activity;

- Every analyzed phenomenon should be considered in the process of development.

The essence of authenticity can be defined in a number of hypostases:

- as a historical category;

- as a given process-modifying character;

- as a process of resolving the contradiction between its statics and dynamics.

Therefore, the vocation of the performer is to seize what is felt and what is still untoward.

\section{Ethics as a category of musician-performer's thinking}

The volume of the unit does not allow us to disclose this topic optimally, and therefore, we will restrict ourselves to the basic provisions for understanding the concept of the category ethics.

What are the possible arguments about the ethics of personality, which is the bearer of complex interrelated psychological processes controlled by human consciousness? This question can be answered unambiguously: the norms of human behavior and its relation to people in society through different forms of formation (family, art, etc.) form the essence of this concept.

The next question is the elaboration of the previous one: can or should the paradigms of ethics, postulates be the same in a variety of interpersonal

${ }^{8}$ Давидов М. Теоретичні основи формування виконавської майстерності баяніста. К.: Музична Україна, 1997. 240 с. 
relationships? And also: which criteria of self-evaluation constitute criteria of general ethical morality and how do the latter affect a particular person, although these - at first glance - separate understandings are components of a single phenomenon?

First of all, you need to refer to the primary sources.

"Ethics (Latin ethic, from Greek - custom) 1) philosophical science, which defines morality as one of the forms of social consciousness; 2) norms of behavior, a set of moral rules of a particular social group"9.

"Ethics [Greek. ethos - custom, rule] - 1) the philosophical doctrine of morality, its origin, development and role in the social and personal life of people; 2) a set of norms of conduct, the morality of any social or professional group" $"$.

If we carefully examine the concept of the category of ethics presented in the dictionary transcription, one can see that, in their entirety, they are formulated in terms of awareness, they differ only in form and logical diversity (that is, from the permutation of words the essence does not change). However, this does not mean that in another transcription there is no proper, special semantic understanding of the concept that makes a certain novelty in its vision. Namely: in this variant, in contrast to the first, morality is considered procedurally - as an origin-developmentrole. Similar understanding relates to transcription-comparison of the category morality.

"Moral (French morale, from Latin moralis - moral): 1) a social institution, one of the forms of social consciousness; a system of views and ideas, norms and evaluations that govern the behavior of people. Moral performs cognitive, evaluating educational functions. Subject of special study of ethics; 2) portable - instructive conclusion from a certain event; instruction, instruction" $"$.

"Moral [French. morale lat. moralis - moral mos (moris) custom, will; law; property] - 1) a set of norms and principles of human behavior; one of

9 Словник іншомовних слів / [ред. О. Мельничук]. 2-ге вид. Київ: Головна редакція Української Радянської Енциклопедії, 1985. 968 с.

${ }^{10}$ Сучасний словник іншомовних слів [уклад. О. Скопненко, Т. Цимбалюк]. Київ: Довіра, 2006. 789 с.

11 Словник іншомовних слів / [ред. О. Мельничук]. 2-ге вид. Київ: Головна редакція Української Радянської Енциклопедії, 1985. 968 с. 
the forms of social consciousness; 2) Instructive conclusion; 3) p. instruction" ${ }^{\text {, }}$.

Why do we use the phrase-category in relation to ethics and morals? Because they are inseparable. And if ethics is a science that defines morality, then the latter is the methodological basis for understanding ethics.

The custom, the norm, the principles of human behavior are forms of social consciousness. All these concepts must be perceived and understood architecturally in order to understand their significance in relation to one another. Let's consider the primary of them as those that constitute the basis for further formation of phrases used in disclosing the essence of the topic.

Custom. In this concept, first of all, the historical achievements of human communication are recorded, as a result of which certain ceremonies, relations, which reproduce the very formation of the moral norms of coexistence in specific social circumstances, have arisen. It is clear that in relation to an individual, this concept is less contextual than in relation to human relations in general. That is, in relation to each person, it is more adequate and related to the notion of habit.

The concept of habit is more typical to an individual. This is explained by the natural differentiation of the individual: since one person is used to it, another cannot be perceived; depending on their physiological condition, system of education, conditions of life, etc. However, this does not mean the possibility of kinship with these features.

If we consider the custom as the result of awareness of reality and the motivational orientation of a person, then these are the phenomena of human psychology that arise in the process of their formation precisely in interpersonal communication. Outside this custom takes on a different meaning: this is a habit that defines certain acquired attitudes in the person itself (for example, the daily mode of human existence, or its nonregimen). After all, the customs of a person, which are laid down in its psychology and have continental-genetic roots, constitute a certain system (or unsystematic), which has the properties that come from the influence of the natural environment, the submission to it (or vice versa), the manner of education, etc. That is, the customs of a particular subject are due to many

12 Сучасний словник іншомовних слів [уклад. О. Скопненко, Т. Цимбалюк]. Київ: Довіра, 2006. 789 с. 
factors, namely: the observance of the surroundings, or the expression of protest to this environment and the desire for the implementation of social changes in accordance with their own expression of will (a kind of protestlike form that constantly exists in any society. In various words, there are at least two (as it is known, in the "pure" form, such persons can be represented conditionally-imaginary), moral-ethical types of persons: the first respects historic customs because they are raised on them, they respect and adhere to them, study them and bring them to life. The other category includes those who neglects, protest the traditions and impose their own habits (and consequently - people, society), their vision of morality (or vice versa - immorality). It is logical to consider the custom from the point of view of the understanding of parenting, and not from the point of view of its absence and moral infinity.

Another aspect of understanding this position imposes and opens up previous customs and directs them. Previous consciousness obeys such individuals who deny the traditional thinking and insist on their own vision of traditional thinking.

The custom is a phenomenon of historical-procedural origin, because the previous ethical and moral achievements of human communication took place and accumulated first in a rather narrow circle, that is, in small territories (village, settlement). It is here that the language and sound intonational dialects and peculiarities of the behavior of human selfexpression are derived. And here morality reflects these procedural actions in human psychology: namely, the influence of local genetic origin both in direct physiological expression and in subsequent epistemological perspectives of individuality, as well as in different kinds of intonation (language-conceptual, musical).

How to habits form? What roots prevail in their formation genetically reflexive or socially acquired? Most likely - the first. After all, they are inseparable from the genetically engineered needs (in breathing, nutrition, movement), and are the established qualities inherent in all without exception.

On the other hand, the habit (as distinct from the custom) can be regarded as a phenomenon of mobile nature inherent to an individual: it is procedurally acquired, because a person is used to it. It is not provided by nature. That is, if you briefly express an opinion on the difference between 
the notions of habit and habit, then we can state: everything is acquired in the process of life and has a well-established character with respect to an individual, can be defined as a habit.

The habit of the individual - the quality of life. It is aimed at satisfying their own needs.

But how to treat the custom - as a duty to follow something sacred? This is a habit, or a custom, or - and both (for example, the memory of those who are not with us)? However, for a person brought up in "Ego-me" (the term S. Freud), their habits of any origin (and moral, also) may have the status of personal customs.

We must not forget that the custom assumes the existence not in individual, but also in interpersonal relationships. Therefore, the very existence of a custom requires the presence of at least two individuals. These thoughts can be refuted.

But, in our opinion, the custom is still an interpersonal phenomenon.

The nature and scale of interpersonal relationships has both a micromacro-scale and a different nature of occurrence, diverse to the extent that it is a person (passively or actively). In the process of historical evolution of interpersonal relations, crystallization or recrystallization of certain customs takes place and will take place. In this regard, B. Asafiev's had a rightful thought: "So the music of the composer, growing from the intonations of previous epochs, becomes the object of intonation of the performer-professional as well as the broad social classes of listeners, nourishes the music and the whole spiritual culture of the next generations of mankind. This process takes place while the vital content of the intonations of this music will not be exhausted, moving in part, in another form, into the creativity of new eras" ${ }^{\text {"13 }}$.

Authenticity keeps historically frozen samples. And this is natural. However, evolutionary-social processes, undoubtedly affect the historical archaic heritage. It is also known that assimilation processes, both physiological and moral, are generating both in the micro-and macroenvironments (quantitative and qualitative volumes of social groups ethnic groups, tribes, nations, peoples) a new, previously not existing custom.

${ }^{13}$ Асафьев Б. Избранные труды: в 5 т. М.: АН СССР, 1957. Т. 5.388 с. 
The historical aspect in the study of ethics in general, and individually musical, consists in the meticulous understanding of the components of this concept. Aspects of awareness of historical in general and musical and performing understanding of the concept of ethics need to be analyzed in order to know the truth, which seek researchers of all scientific disciplines (precise and humanitarian), since ethics is the most expressive indicator of intelligence, talent, temperament of man, level-criterion of historicalprocedural. Consequently, ethics is a criterion for historically composed human relationships.

The volume of the unit does not allow a broader view of this topic. Therefore, we will continue its consideration in a narrowly professional executive-musical aspect.

Thus, if we consider ethics as a science about morality and one of the forms of social consciousness and generalized norms of behavior, and morality - as a system of views and ideas, then it can be presented in purely human relations, and we can hope for the following thoughts.

So, how ethics-morals can be filed in musical art? That is, how are human senses passed through the sound intonation - the bearers of morality?

The connection of morality with the temperament, which leads to the implementation of instinctive lawsuits, exists in many combinations, for example: one side recognizes and restrains its own physiological reflex instincts influenced by reason, education, education, etc.; the other side in various ways seeks for so-called physical comfort, without touching (due to the inability, first of all) of the existing historically acquired moral norms, is fanatically guided by its own norms of morality in which it is raised and adhered to (for example, directions of dubious morals, etc.). The third party acts independently of any moral principles.

Morality is personal - the motivation of each individual. That is, morality is the psycho-physiological needs of the individual.

Ethics is musical. What are its specific peculiarities? What is common with ethics in general?

The ethics of musical and performing arts cannot exist beyond the general giftedness and education of the performer.

If you talk about the norms of morality in musical art (musicalperforming, in particular), it is necessary to determine what exactly these 
norms form? First of all, in our opinion, this is a mood, a love of art, that is, a spiritual and spiritual, and not a mercantile source of communication, when a person cannot exist beyond the aura of perception of music (passive perception) and the ability to independently reproduce it and create a new vision of musical art.

This - the basic principles began in the ethics of art, because the artist generates new feelings that he receives from works of art. After all, if a person likes musical art without realizing the origin of this love, she perceives it naturally and engages in communicating with its creators through musical compositions with great inspiration without noticing their own energy and intellectual costs.

On the other hand, if on this basis the musician-performer creates something new, for example, a musical work or the concept of its interpretation, then the result may be unpredictable, which manifests itself subconsciously (remember D. Mendeleev, who devoted a lot of intellectual energy to the creation of the "Periodic Table of Elements" and which in the final version appeared to him in the dream).

So, if you understand the notion of ethics as the norm of communication between people, and music reveals these norms through sensation, this means that the primary task of the performer is the ability to "see" a particular creator (composer). And this, in turn, speaks of the most correct, objective interpretation of his musical works in order to learn the composer's intentions that reflect his ethical and moral views. They are, first of all, embodied in musical matter. It is in this process that education and educational traditions are required.

It is necessary to consider the ethical rules of the musician-performer regarding the definition of a number of issues that give an understanding of this concept-category. Here is an interpretation of the notion of the category "norm": [lat. norm - rule, example]: 1) mandatory order, which must be followed; Legitimate rules that determine the order, the principles of constructing something, etc.; 2) the measure is set, the value of something, for example, the output of the N." ${ }^{.14}$.

${ }^{14}$ Сучасний словник іншомовних слів [уклад. О. Скопненко, Т. Цимбалюк]. Київ: Довіра, 2006. 789 с. 
We draw attention to its figurative color of the notion of "norms". Namely: there are "norms" in musical-performing practice?

First, the rules of ethics-morality are manifested in the interpersonal communication between the teacher and the student, and, depending on the appropriate education, the future creative achievements of the pupil's performer depend largely on the future. That is, this is the normal period of becoming a person-student. If the teacher has a certain executive experience, as well as practice in teaching executive disciplines (ensemble, orchestra class, etc.), then the learner-performer will receive the proper skills that prompts him to self-improvement.

Ethical relations are constantly taking place in music art: it is communication with previous generations thanks to graphically-fixed musical notes; communication with teachers who give knowledge of previous experience; communication with new works of contemporary composers. These factors determine the artist's self-determination, since the performer focuses on them both in perception and in the comprehension of intellectual-sensory information.

Consideration of this topic can be multifaceted, since the subject relates to the individuality of the artist-performer, who seeks to study the achievements of the historical mission; they give an opportunity to evaluate themselves and others.

Ethics, if you give it a general definition, for an artist-performer, above all, is a set of at least the following factors: a low threshold of sensitivity (according to V. Nebelitsyn) + education + executive actions of the artist-professional.

The low threshold of sensitivity in psychology has the highest degree of perception by the performer of the natural environment and human relationships. In musical intonation, this manifests itself in the ability to reproduce spiritual impulses-performances in the tension of a separate tone, and in the tension of tones horizontally and vertically - in the full complement of the mutual influence of composer means of musical expression and mobile performing expressive means.

Only in the total volatility of these indicators there are ethical norms that optimally characterize the professionalism of the musician-performer. A person is highly gifted, well-educated and trained, which means it is a potential carrier of ethical norms of high musical art. 
Education is the ability not only to perceive information, but also to create a "new ethical".

The inspiration of the musician-performer is to bring people what they cannot do due to different circumstances, but what they want for their spiritual satisfaction. This is the task for a person who can do this, that is, a person-performer.

A person who cares for others in general and each individual, and has a brilliantly owning art has a moral right to ethical assessment of what is happening in musical art. Such an assessment is precisely in the interpretation, in deep respect for the author of the musical work, in deciphering the feelings of the author, and, also, in his own abilities, not to disturb and neglect the work, but to ennoble him with his righteous emotions. That is, these directions have a deep respect for the subject of art, they form a person-performer's own feelings-feelings beyond the standard.

The next question is the ethical norms and principles that guide the musicians-performers in preparing a musical work to perform before the listening audience.

In this respect, the performer is the most responsible person, who embodies not only his own needs, which is important for the creative person, but also satisfies the aesthetic needs of many listeners.

The performance of the listening audience has a different level, and the performer feels this during his own concert performance. That is, feedback-reaction in the tandem, the performer-listener goes by suddenly: if the listening audience does not correspond to the ethical representations of the performer, then his subsequent actions are directed at solving extreme problems that have an interpretive-improvisational character.

The motivation of these operative improvisation actions is directed at the implementation of such adjustments of presentation of meaningful sonority, which have not only ethical and moral, communicative orientation, but also the psycho-physiological aspect. After all, the performer in his ethical and moral quest must know how their results can be communicated to listeners with different psychology of perception and evaluation of musical art.

If we understand the notion of ethics as the norm of communication between people (and music reveals these norms through sensations), this 
means that the chief task of the performer is to "see" a particular personauthor of an executable musical work. And this, accordingly, requires the clearest expression of the concept interpreted by the artist, in the context of means of composing speech, in order to know the author's intentions reflecting his moral and ethical views embodied in a particular musical matter. It is this implementing actress who needs the appropriate theoretical literacy and support, both on the tradition of the performance of this work, and on the tradition of musical performance in general.

The intonational culture in the transfer of the subtle human feelings is the basis of the artist's ethics. How is it explained? First of all, the ethics of the musician-performer is not a simple phenomenon, as it seems to somebody at first sight. Ethics in the broad sense is a philosophy of life. The principles of morality that the musician guides consciously or unknowingly influences ethical and moral norms-principles that appear in music, primarily in understanding the style of the composer and his interpretation, as well as self-expression and self-affirmation of the performer himself.

It should be noted that the conscious and unconscious in revealing these norms manifests itself in their own way: on the one hand (analytical type of thinking), the need for rational understanding (interpretation) of a musical work is manifested; on the other (artistic type of thinking) - the performer is sufficiently deep acquaintance with the musical text, and the rich musical and auditory intonation sensitivity of the musician "automatically" triggers the embodiment of the stylistic features of the musical work (the composer), which means - the subconscious embodiment of ethics-morality without their prior awareness of the performer. However, the last of these types of performers is considered by us as exceptional, as evidenced by the pedagogical experience. Therefore, in educational practice, we must first of all focus on the emotionallyrational type of performer, as the most optimal in terms of combining the logic of disclosing the content and the form of musical works - with the emotional personal expression of the performer on the concert stage. The personality of the artist-performer is constantly formed. This is an unprecedented time process. Therefore, knowing the norms of morality, 
we must understand their vision in decoding the means of composing speech.

Fragmentary considerations encourage further reflection on the ethical standards of the outlook of the musician-performer. All the main features of the personality of the musician, which characterize his general culture, such as selflessness in art, humanity, kindness, high morality of behavior in society, ability to work, understanding of the laws of historical development and art, artistic and aesthetic perception of reality, are manifested in his performing activities as certain level of culture of feelings.

\section{CONCLUSIONS}

So, in relation to the interpretative aspect of the thinking of the musician-performer one can state: the interpretation as a phenomenon of musical performing aesthetics, in accordance with its purpose which bears a certain idea of the composer and the perfect concept of the artist, is aimed at enriching the artistic reproducing and perceiving tastes.

The most specific types of activities in the process of their formation and development go through a single opportunity of implementationembodiment - active individuality as an individual who has only his/her peculiar qualities.

The interpretation does not exist outside the personal outlook of the interpreter, since the individual mental qualities of the performer and his personal orientation in the musical space affect both the intellectual and the sensual processes of perception and awareness of his/her artistic and aesthetic, musical and creative preferences.

The personal world of the musician-performer cannot be formed beyond the interpersonal relations, which represent the process of mutual enrichment (teaching, aesthetic, moral and ethical communication, etc.). The essence of interpersonal relationships is in the process of moral-spiritual-intellectual communication, no matter what form it would have (literature, painting, music, direct communication ...).

Musical performance does not exist beyond the comprehension of universal human feelings and individual searches for the creative 
realization of their results. This pattern characterizes the artist-performer of creative orientation in the process of artistic activity and intellectual and emotional accumulation, and generates a higher level of perception and mastery of the artist's active world of vision in relation to the initial level of perception.

Understanding of his/her own ability to reproduce and create the relevance of knowledge in general, and as a result, the skill of the embodiment and presentation of the artistic concept of a musical composition is an indication that this is the highest level of purpose of musical and performing arts.

The initial source of interpretive needs and motivations in the perception of the performer-musician is determined by what the performer must say to the listener in a musical language, even when he/she feels it, but he/she is not able to explain these thoughts-reflections to himself/herself, to realize them, meaning to provide sensual- emotional and intellectual evaluation.

The broad concept of interpretation reflects the peculiarities of human existence since musical art is a part of human nature, a natural reflection of reality, which has a temporal-historical character, fixed in certain sign-conceptual systems and is aimed at further discovering the past and predicting the future. It means both historically acquired and future achievements in the field of knowledge of a person himself/herself and the outlook as a whole, and, therefore, his/her mission in this process.

\section{SUMMARY}

This article is devoted precisely to the complete representation of the artist of his/her own involvement in interpreting searches. That is, considering one of the fundamental problems of art studies and musical and performing arts is the motivational aspiration of authenticity as the primary source of creative thinking.

The process of forming a particular genre in art is the primary source. In conditions of megacity formation of a person as a person there are significant changes, which, without a doubt, have other continuum-genetic features compared with the predetermined ones. Certain natural environment peculiarly forms the ethical and moral views of a person. 
Historical transformations lead to a review of the moral and ethical preferences of previous times. And this is the essence of natural origin, if these phenomena are considered in terms of their content. In this regard, ethics as a phenomenon of the highest order of formation of personality, acquires a historical-procedural nature without losing its essential foundations.

The concept of ethics is considered, in the philosophical sense, as one of the forms of social consciousness (certain rules and laws of communication between people in terms of their moral conditionality). The content of this concept as a category of musical and performing thinking is noted. Ethics embodies the historical experience of human relations in the fullness of their content.

Ethics in musical-performing arts cannot be separated from universal human ethical standards, since it is one of the specific forms of human existence-communication. It (musical and performing arts) can also be considered as a specific aspect of personal sensual-intellectual, moral and ethical relations.

\section{REFERENCES}

1. Асафьев Б. Избранные труды: в 5 т. М.: АН СССР, 1957. Т. 5. $388 \mathrm{c}$.

2. Давидов М. Теоретичні основи формування виконавської майстерності баяніста. К.: Музична Україна, 1997. 240 с.

3. Маркова О. Питання теорії виконавства: Матеріали до курсу теорії виконавства для магістрів і аспірантів. Одеса: Астропринт, 2002. 128 c.

4. Медушевский $\mathrm{B} . \quad \mathrm{O}$ закономерностях и средствах художественного воздействия музыки. М.: Музыка, 1976. 254 с.

5. Назайкинский E. Музыкальное восприятие как проблема музыкознания / Восприятие музыки. М.: Музыка, 1980. С. 91-111.

6. Сокол А. Исполнительские ремарки, образ и музыкальный стиль. Одесса: Моряк, 2007. 276 с.

7. Словник іншомовних слів / [ред. О. Мельничук]. 2-ге вид. Київ: Головна редакція Української Радянської Енциклопедії, 1985. 968 с. 
8. Сучасний словник іншомовних слів [уклад. О. Скопненко, Т. Цимбалюк]. Київ: Довіра, 2006. 789 с.

Information about the author:

Zaets V. M.

Candidate of Art Criticism, Associate Professor, National Music Academy of Ukraine named after P. I. Tchaikovsky 1/3-11, Architector Gorodetsky str., Kyiv, 01001, Ukraine 